EESTI NSV TEADUSTE AKADEEMIA TOIMETISED. IX KOIDE

FOOSIKALIS-MATEMAATILISTE JA TEHNILISTE TEADUSTE SEERIA, 1960, NR. 4

ИЗВЕСТИЯ АКАДЕМИИ НАУК ЭСТОНСКОИ ССР. ТОМ IX СЕРИЯ ФИЗИКО-МАТЕМАТИЧЕСКИХ И ТЕХНИЧЕСКИХ НАУК. 1960, № 4

\title{
О ХИМИЧЕСКОМ СОСТАВЕ СЕРНИСТЫХ СОЕДИНЕНИИ СЛАНЦЕВОГО БЕНЗИНА
}

\author{
о. ЭИЗЕН, \\ кандидат технических наук
}

Ю. РИККЕН

При исследовании химического состава нефти большое внимание уделяется сернистым соединениям. Изучение последних весьма успешно ведется в Башкирском филиале Академии наук СССР коллективом сотрудников под руководством профессора Р. Д. Оболенцева $\left[{ }^{1,2}{ }^{2}\right]$. Общеизвестны также работы по исследованию сернистых соединений, проводимые Американским нефтяным институтом. Наличие обширных литературных материалов по методике исследования и химическому составу сернистых соединений обусловлено запросами и нуждами нефтяной промышленности.

Трудно переоценить и значение исследования сернистых соединений, содержащихся в сланцевой смоле. Несмотря на это, количество работ, касающихся химического состава сернистых соединений сланцевой смолы, крайне малочисленно. Исследованием группового состава сернистых соединений занимались Уск и Столер [3], которые установили изменение последнего под воздействием рафинации сланцевого бензина, Обычно исследование сернистых соединений в продуктах, получаемых из смолы эстонских горючих сланцев, ограничивалось определением общего содержания серы в узких или широких фракциях [4]. Более детально исследование сланцевой смолы было предпринято Силландом $[5,6]$, который изучил распределение сернистых соединений и их групповой состав. Известного внимания заслуживают также разработанные им методы определения группового состава сернистых соединений.

Названные работы являются, по существу, единственными источниками, касающимися изучения сернистых соединений эстонской сланцевой смолы.

Более широко представлены работы по изучению сернистых соединений, содержащихся в продуктах термической переработки сланцев других месторождений Советского Союза $\left[{ }^{7-9}\right]$. Однако большая часть их содержит результаты опытов, имеющих уже 30 -летнюю давность.

Из соответствующих зарубежных исследований следует отметить работу Лундквиста $\left[{ }^{10}\right]$, которому удалось выделить и идентифицировать из смолы шведских сланцев некоторые производные тиофена, дисульфиды и меркаптаны. Ряд производных тиофена был выделен из колорадской сланцевой смолы Қиннеем [1"]. Различные сернистые соединения, в основном тиофенового ряда, были установлены в австралийской, шотландской и других сланцевых смолах.

В настоящей работе приведены дополнительные данные, касающиеся распределения сернистых соединений в бензиновых фракциях и идентификации некоторых из них (в частности, соединений тиофенового ряда).

В табл. 1 представлены данные об общем содержании серы в различных сланцевых смолах.

Как видно из приведенной таблицы, содержание серы в суммарных смолах зависит от системы термической переработки топлива и колєб- 
лется в пределах $0,7-1,1 \%$. Наибольшее количество серы содержится в смоле камерных печей. Данные распределения серы в зависимости от температуры кипения смолы, представленные на фиг. 1, показывают, что общий максимум содержания серы находится в пределах кипения $120-190^{\circ}$. С повышением границы кипения фракций количество серы непрерывно уменьшается, доходя до $0,5-0,6 \%$.

таблица 1

Содержание серы в сырых сланцевых смолах (вес. \%)

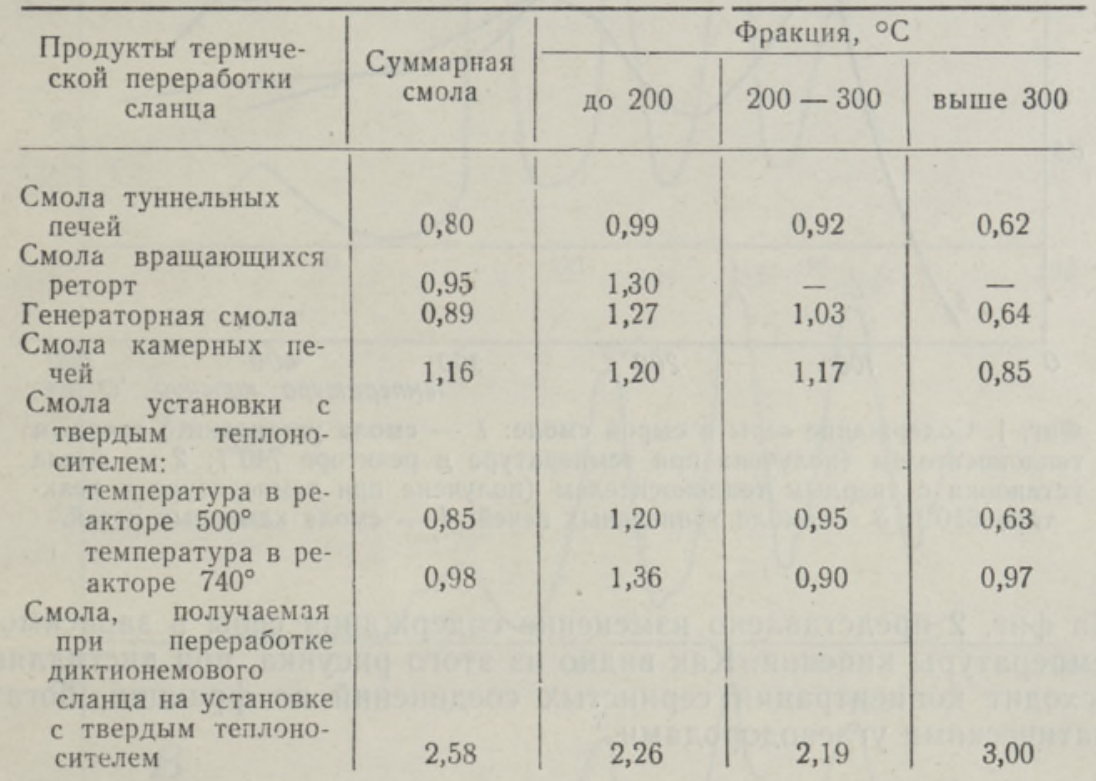

Сланцевые фенолы, в отличие от нейтральных компонентов смолы, весьма бедны серой. Поэтому после удаления фенолов содержание серы в обесфеноленной смоле несколько возрастает.

Если проследить йа фиг. 1 за изменением содержания серы, то можно увидеть, что последнее протекает ровно и имеет единственный максимум в пределах $130^{\circ}$. Отсюда можно заключить, что в бензиновой фрағции сернистые соединения распределены равномерно в пределах всей фракции, без каких-либо значительных областей их повышеннюго сосредоточения.

Для проверки этого предположения были поставлены следующие опыты.

Бензиновые фракции смол туннельных печей, вращающихся реторт, установки с твердым теплоносителем, а также газбензин камерных печей подвергались дистилляции в колонне с разделяющей способностью в 60 теоретических тарелок. Исходные продукты, за исключением газбензина камерных печей, предварительно дефенолировались $20 \%$-ным водным раствором едкой щелочи. В табл. 2 приведены наиболее важные показатели исходных продуктов и показано связанное с процессом дефеноляции изменение удельного веса и содержания серы в бензинах.

Количество исходных бензинов, взятых для дистилляции, составляло 15-30 кг. Фракционирование осуществлялось при флегмовом числе, равном 60 , причем отбирались $1-5$-градусные фракции, количество которых колебалось от 40 до 60. В полученных фракциях определялись их 
физико-химические токазатели. Содержание серы определялось ламповым методом.

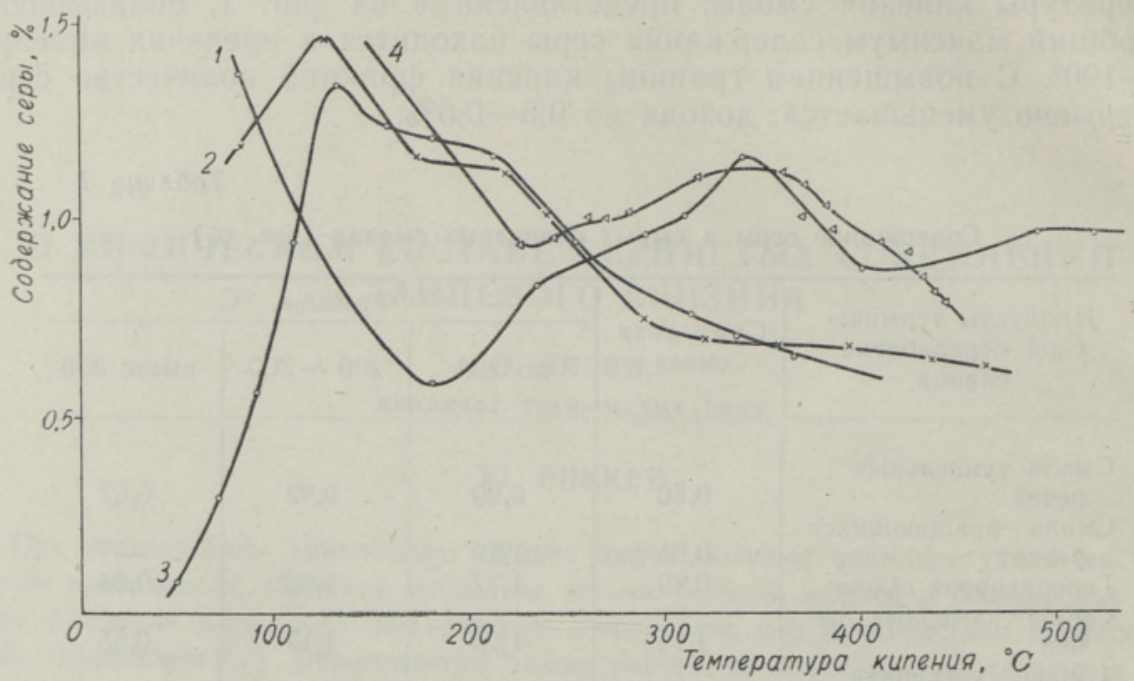

Фиг. 1. Содержание серы в сырой смоле: 1 - смола установки с твердым теплоносителем (получена при температуре в реакторе $740^{\circ}$ ); 2 - смола установки с твердым теплоносителем (получена при температуре в реакторе $\left.510^{\circ}\right) ; 3$ - смола туннельных печей; 4 - смола камерных печей.

На фиг. 2 представлено изменение содержания серы в зависимости от температуры кипения. Как видно из этого рисунка, при дистилляции происходит концентрация сернистых соединений во фракции, богатые ароматическими углеводородами.

таблица 2

\section{Результаты процесса дефеноляции различных сланцевых смол $20 \%$-ным раствором едкой щелочи}

\begin{tabular}{|c|c|c|c|c|c|c|}
\hline \multirow[b]{2}{*}{$\begin{array}{c}\text { Продукты различных } \\
\text { систем термического } \\
\text { разложения сланца }\end{array}$} & \multicolumn{3}{|c|}{ Сырая смола } & \multicolumn{3}{|c|}{ Дефенолированная смола } \\
\hline & $d_{4}^{20}$ & $\mathrm{~S}, \%$ & $\begin{array}{c}\text { Содержание } \\
\text { кислых } \\
\text { соединений, } \\
\text { об. \% }\end{array}$ & $d_{4}^{20}$ & $\mathrm{~S}, \%$ & $\begin{array}{c}\text { Содержание } \\
\text { кислых } \\
\text { соединений, } \\
\text { об. \% }\end{array}$ \\
\hline $\begin{array}{l}\text { Легкая смола уста- } \\
\text { новки с твердым } \\
\text { теплоносителем } \\
\text { комбината «Киви- } \\
\text { ыли» } \\
\text { Легкие фракции тун- } \\
\text { нельных печей ком- } \\
\text { бнната «Кивиыли» } \\
\text { (пропорциональная } \\
\text { смесь) }\end{array}$ & 0,8349 & 1,07 & 9,0 & 0,8174 & 1,03 & 0,0 \\
\hline $\begin{array}{l}\text { Сырой бензин комби- } \\
\text { ната «Кохтла» } \\
\text { Газобензин камерных } \\
\text { печей комбнната } \\
\text { им. В. И. Ленина }\end{array}$ & 0,7804 & 1,07 & $\begin{array}{l}4,8 \\
3,0\end{array}$ & $\begin{array}{l}0,8053 \\
0,7691\end{array}$ & $\begin{array}{l}1,10 \\
1,10\end{array}$ & $\begin{array}{l}0,0 \\
0,0\end{array}$ \\
\hline
\end{tabular}


О химическом составе сернистых соединений сланцевого бензина

361
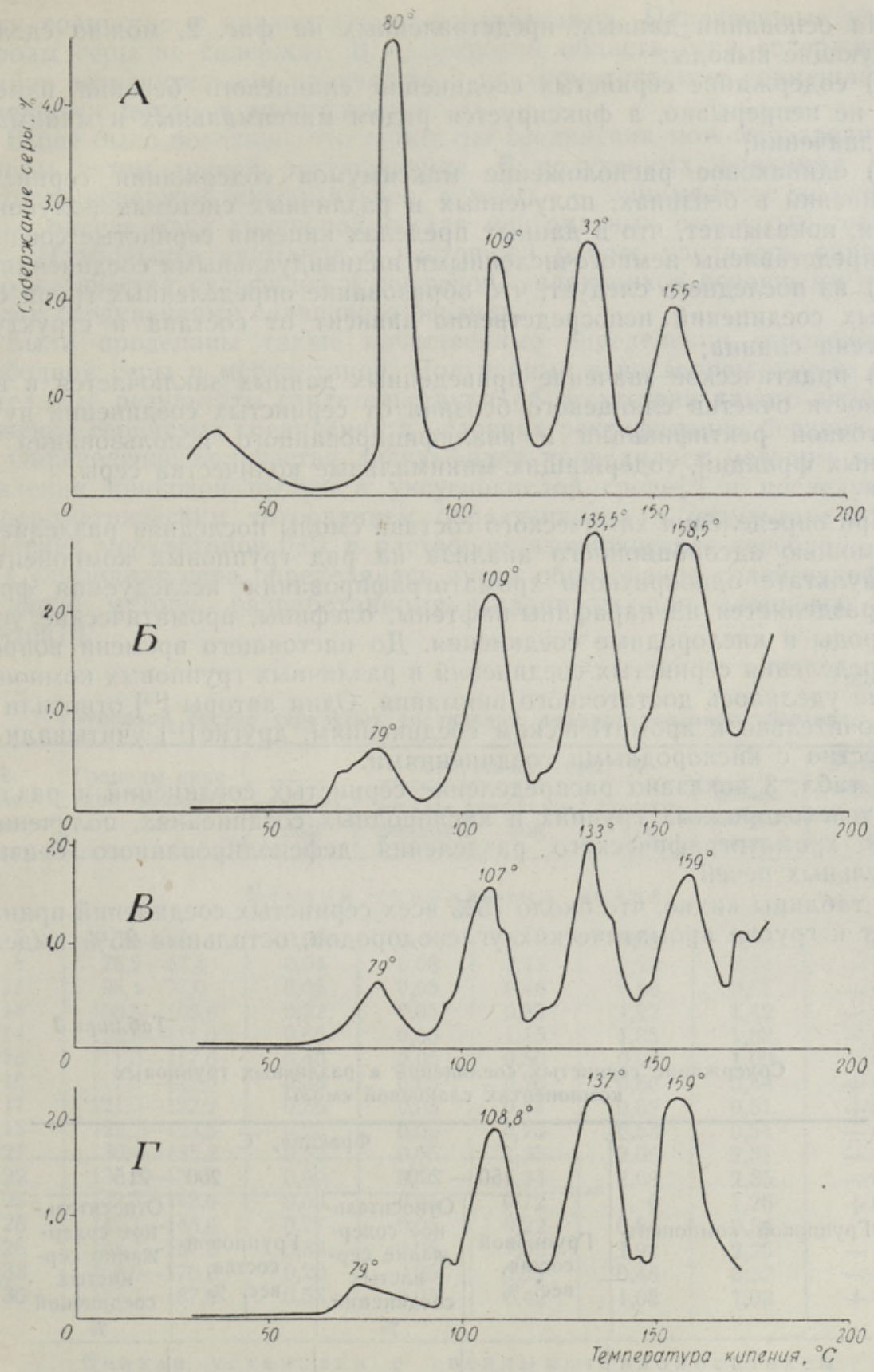

Фиг. 2. Содержание серы в сланцевых бензинах: $A-$ бензин камерных печей; $E$ - бензин вращающихся реторт; $B$ - бензин установки с твердым теплоносителем; $\Gamma$ - бензин туннельных печей.

Фракции, лишенные ароматических углеводородов, содержат мало сернистых соединений. Распределение нейтральных сернистых соединений в сланцевом бензине, как видно из фиг. 2, не зависит от системы полукоксования.

6 ENSV TA Toimetised T-4 60 
На основании данных, представленных на фиг. 2, можно сделать следующие выводы:

1) содержание сернистых соединений сланцевого бензина изменяется не непрерывно, а фиксируется рядом максимальных и минимальных значений;

2) одинаковое расположение максимумов содержания сернигіых ссединений в бензинах, полученных в различных системах полукоксования, показывает, что в данных пределах кипения сернистые соединения представлены немногочисленными индивидуальными соединениями;

3) из последнего следует, что образование определенных групп сернистых соединений непосредственно зависит от состава и структуры керогена сланца;

4) практическое значение приведенных данных заключается в возможности очистки сланцевого бензина от сернистых соединений путем его точной ректификации и квалифицированного использования отдельных фракций, содержащих минимальные количества серы.

При определении химического состава смолы последняя разделяется с помощью адсорбционного анализа на ряд групповых компонентов. В результате однократного хроматографирования исследуемая фракция разделяется на парафины-нафтены, олефины, ароматические углеводороды и кислородные соединения. До настоящего времени вопросу распределения сернистых соединений в различных групповых компонентах не уделялось достаточного внимания. Одни авторы $\left[{ }^{13}\right]$ относили их исключительно к ароматическим соединениям, другие [12] учитывали их совместно с кислородными соединениями.

В табл. 3 показано распределение сернистых соединений в различных углеводородных группах и кислородных соединениях, полученных путем хроматографического разделения дефенолированного бензина туннельных печей.

Из таблицы видно, что около $75 \%$ всех сернистых соединений принадлежат к группе ароматических углеводородов, остальные $25 \%$ выделя-

Таблица 3

Содержание сернистых соединений в различных групповых компонентах сланцевой смолы

\begin{tabular}{|c|c|c|c|c|}
\hline \multirow[b]{3}{*}{ Групповой компонент } & \multicolumn{4}{|c|}{ Фракция, 'C } \\
\hline & \multicolumn{2}{|c|}{$150-200$} & \multicolumn{2}{|c|}{$200-215$} \\
\hline & $\begin{array}{l}\text { Групповой } \\
\text { состав, } \\
\text { вес: } \%\end{array}$ & $\begin{array}{c}\text { Относитель- } \\
\text { ное содер- } \\
\text { жание сер- } \\
\text { нистых } \\
\text { соединений, } \\
\%\end{array}$ & $\begin{array}{c}\text { Групповой } \\
\text { состав, } \\
\text { вес. } \%\end{array}$ & $\begin{array}{c}\text { Относитель- } \\
\text { ное содер- } \\
\text { жание сер- } \\
\text { нистых } \\
\text { соединений } \\
\% \\
\end{array}$ \\
\hline Иеходная фракция & - & 100,0 & - & 100,0 \\
\hline $\begin{array}{l}\text { Парафиновые углево- } \\
\text { дороды }\end{array}$ & 21,2 & 0,0 & 19,5 & 0,0 \\
\hline $\begin{array}{l}\text { Олефнновые углево- } \\
\text { дороды }\end{array}$ & 38,5 & 1,0 & 34,5 & 0,7 \\
\hline $\begin{array}{l}\text { Ароматические угле- } \\
\text { водороды }\end{array}$ & 28,5 & 76,6 & 33,9 & 74,5 \\
\hline $\begin{array}{l}\text { Кислородные соеди- } \\
\text { нения }\end{array}$ & 11,8 & 22,4 & 12,1 & 24,8 \\
\hline
\end{tabular}


ются совместно с кислородными соединениями. Парафиновые углеводороды серы не содержат. В олефиновой области сера содержится в крайне незначительном количестве и на хроматограмме совмещается в основном с цикло- и диолефинами.

Выше было показано, что сернистые соединения можно разделить на группы путем точной ректификацин. В полученных фракциях, часть которых содержит максимальное, а часть - минимальное количество серы, определялся групповой состав нейтральных сернистых соединений. Наибольшее внимание в настояшей работе уделялось определению количества сульфидов и тиофенов, являющихся основными сернистыми соединениями сланцевого бензина.

Были проделаны также качественные определения сероводорода, свободной серы и меркаптанов. Полученные в последнем случае отрицательные результаты свидетельствуют об отсутствии какого-либо разложения сернистых соединений в условиях ректификации бензина.

Определение количества дисульфидов проводилось методом восстановления цинковой пылью в уксуснокислой среде [ $\left.{ }^{6}\right]$ и последующим амперометрическим титрованием образующихся в результате восстановления меркаптанов $0,01 n$ раствором азотнокислого серебра.

Сульфидная сера определялась путем образования солей сульфония согласно методу, разработанному Силландом для сланцевых продуктов [6].

Таблица 4

Групповой состав сернистых соединений дефенолированного бензина

\begin{tabular}{|c|c|c|c|c|c|c|c|}
\hline \multirow{2}{*}{$\begin{array}{l}\text { 스 } \\
\text { фрак- } \\
\text { ции }\end{array}$} & \multirow{2}{*}{$\begin{array}{l}\text { Границы кипе- } \\
\text { ния фракцин̆, } \\
{ }^{\circ} \mathrm{C}\end{array}$} & \multicolumn{5}{|c|}{ Содержание серы, \% } & \multirow{2}{*}{$\begin{array}{c}\text { Разность } \\
\text { общей и } \\
\text { суммарной } \\
\text { серы }\end{array}$} \\
\hline & & $\begin{array}{c}\text { сульфид- } \\
\text { ной }\end{array}$ & $\begin{array}{l}\text { дисуль- } \\
\text { фндной }\end{array}$ & $\begin{array}{c}\text { тиофено- } \\
\text { вой }\end{array}$ & $\begin{array}{c}\text { суммар- } \\
\text { ное }\end{array}$ & $\begin{array}{c}\text { общее } \\
\text { аналити- } \\
\text { ческие }\end{array}$ & \\
\hline
\end{tabular}

Бензин туннельных печей

\begin{tabular}{r|c|l|l|l|l|l|r}
2 & $36-58$ & 0,02 & 0 & 0 & 0,02 & 0,02 & 0,00 \\
8 & $76,2-87,4$ & 0,04 & 0,03 & 0,13 & 0,20 & 0,24 & $-0,04$ \\
11 & $95,4-97,0$ & 0,05 & 0,05 & 0,48 & 0,58 & 0,61 & $-0,03$ \\
13 & $100,5-106,6$ & 0,32 & 0,05 & 0,85 & 1,22 & 1,42 & $-0,20$ \\
14 & $106,6-111,0$ & 0,65 & 0,05 & 1,15 & 1,85 & 1,88 & $-0,03$ \\
15 & $111,0-117,0$ & 0,40 & 0,05 & 0,50 & 0,95 & 1,00 & $-0,05$ \\
16 & $117,0-121,0$ & 0,35 & 0,05 & 0,20 & 0,60 & 0,54 & $+0,06$ \\
17 & $121,0-122,2$ & 0,36 & 0,05 & 0,17 & 0,58 & 0,51 & $\pm 0,07$ \\
18 & $122,2-123,3$ & 0,25 & 0,05 & 0,23 & 0,53 & 0,54 & $-0,01$ \\
21 & $130,8-135,2$ & 0,50 & 0,05 & 1,51 & 2,06 & 2,31 & $-0,25$ \\
22 & $135,2-139,3$ & 0,69 & 0,05 & 1,34 & 2,08 & 2,35 & $-0,27$ \\
23 & $139,3-142,6$ & 0,53 & 0,05 & 0,72 & 1,0 & 1,26 & $+0,04$ \\
26 & $147,1-148,6$ & 0,27 & 0,05 & 0,22 & 0,54 & 0,54 & 0,00 \\
28 & $152,7-157,2$ & 0,88 & 0,05 & 1,05 & 1,98 & 2,25 & $-0,27$ \\
33 & $168,9-170,2$ & 0,20 & 0,05 & 0,21 & 0,46 & 0,52 & $-0,06$ \\
36 & $185,3-187,6$ & 0,58 & 0,05 & 0,42 & 1,05 & 1,03 & $+0,02$
\end{tabular}

Бензин установки с твердым теплоносителем

\begin{tabular}{l|c|l|l|l|l|l|r}
13 & $78,5-80.2$ & 0,15 & 0,03 & 0,51 & 0,68 & 0,69 & $+0,01$ \\
18 & $92,8-93,6$ & 0,08 & 0,05 & 0,00 & 0,13 & 0,13 & 0,00 \\
26 & $106,5-108$ & 0.30 & 0.05 & 1,27 & 1,65 & 1,62 & $-0,03$ \\
32 & $118,8-120$ & 0,08 & 0,05 & 0,14 & 0,24 & 0,27 & $+0,03$ \\
38 & $128,8-132,6$ & 0,50 & 0,05 & 0,93 & 1,53 & 1,48 & $-0,05$ \\
42 & $138,5-140,1$ & 0,35 & 0,05 & 0,88 & 1,30 & 1,28 & $-0,02$ \\
46 & $145,4-147,2$ & 0,43 & 0,05 & 0,00 & 0,51 & 0,48 & $-0,03$ \\
50 & $158,2-160,9$ & 0,62 & 0,05 & 0,84 & 1,76 & $1,+1$ & $-0,25$
\end{tabular}

6* ENSV TA Toimetised T-4 60 . 
Тиофеновая сера определялась по методу Левита и Хоуарда, согласно которому тиофеновая сера окисляется азотной кислотой до серной кислоты $\left[{ }^{14}\right]$. Количество последней определяется осаждением при помощи хлористого бария. При этом сульфиды окисляются в сульфоны, которые не мешают определению тиофеновой серы.

Данные о групповом составе нейтральных сернистых соединений представлены в табл. 4 .

Показатели табл. 4 свидетельствуют о том, что наличие приведенных на фиг. 2 максимумов общего содержания серы обусловлено в первую очередь концентрацией тиофеновых производных в соответствующих пределах кипения. Весьма интересно также и то, что максимальному содержанию тиофеновой серы иногда сопутствует и наибольшее содержание сульфидной серы.

В зависимости от своего строения сульфидные сернистые соединения делятся на три типа: алифатнческие сульфиды, производные тиофана и производные тиоциклогексана. Наличие значительного количества отдельных соединений, содержащих сульфидную серу, доказывается их более равномерным распределением в исследуемом сырье.

До сих пор полностью отсутствуют данные об индивидуальном составе сернистых соединений смолы эстонского горючего сланца. Причиной этого является незначительное содержание этих соединений в указанной смоле, а также и то, что еще нет достаточно доступного и эффективного метода, который позволил бы изолировать и выделить сернистые соединения из состава такой сложной смеси, как сланцевая смола.

Наибольшие затруднения представляет разделение сернистых соединений и ароматических углеводородов. Лучшим методом здесь следует считать хроматографирование на силикагеле $\left[{ }^{15}\right]$ или окиси алюминия [16].

Существующие химические методы, применяемые для выделения сернистых соединений из смеси углеводородов при помощи различных комплексообразований, являются далеко неполными и не обладают достаточной селективностью. Так, присутствие в смеси олефиновых углеводородов значительно затрудняет процесс выделения сернистых соединений.

Наиболее эффективными физико-химическими методами определения концентрации сернистых соединений являются ректификация, экстракция и адсорбция. Лучшим методом определения индивидуальных сернистых соединений следует считать спектральный анализ. Определение при помощи физико-химических констант применимо лишь при выделении индивидуальных соединений высокой степени чистоты.

В настоящей работе для идентификации сернистых соединений тиофенового ряда применялся инфракрасный спектральный анализ. Концентрат сернистых соединений был получен путем хроматографического разделения бензина установки с твердым теплоносителем (табл. 5).

В случае использования газбензина камерных печей высокая концентрация сернистых соединений была достигнута уже в результате процесса ректификации. Эта концентрация оказалась достаточной для проведения спектрального анализа. Определение спектров велось в инфракрасной области $2000-700 \mathrm{~cm}^{-1}$ на спектрографе ИКС-14. При проведении анализа использовались кюветки из бромистого калия. Толщина слоя концентрата варьировалась в пределах $0,01-0,05$ мм. Продолжительность снятия спектра составляла 45 мин. 
Таблица 5

Результаты обогащения сернистых соединений методом хроматографического разделения

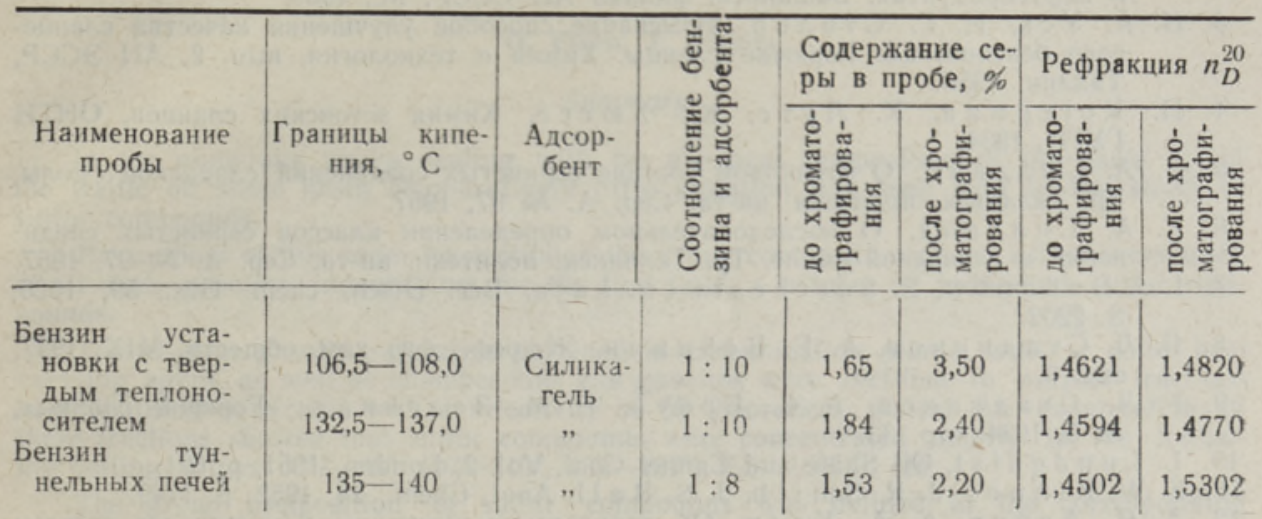

Ниже, в табл. 6, приведены данные идентифицированных произвсдных тиофенового ряда.

Таблица 5

Производные тиофенового ряда, определенные в сланцевом бензине

\begin{tabular}{|c|c|c|}
\hline $\begin{array}{l}\text { Идентифицирован- } \\
\text { ные соединения }\end{array}$ & \begin{tabular}{|} 
Температура \\
кипения, ${ }^{\circ} \mathrm{C}\left[{ }^{17}\right]$
\end{tabular} & $\begin{array}{c}\text { Әкспериментальные значения наиболее характер- } \\
\text { ных абсорбционных максимумов }\left(v, \mathrm{~cm}^{-1}\right)\end{array}$ \\
\hline
\end{tabular}

Бензин установки с твердым теплоносителем

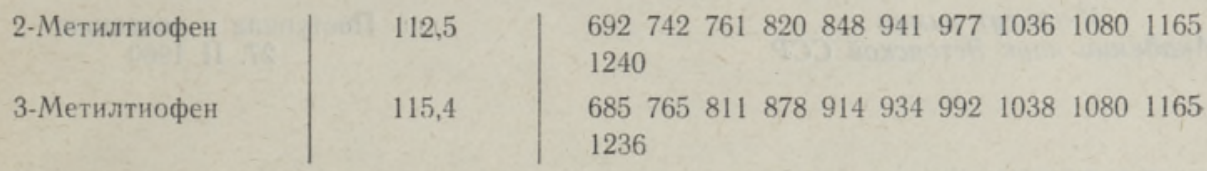

Газбензин камерных печей

Тиофен

2-Метилтиофен

3-Метилтиофен

2,5-Диметилтиофен

2,3-Диметилтиофен

2-Этилтиофен
84,12

112,5

115,4

$135,5-136$

$140,2-141,2$

$132-134$ $\begin{array}{lllllll}713 & 838 & 871 & 904 & 1037 & 1085 & 1250\end{array}$

$\begin{array}{llllllllll}691 & 742 & 763 & 818 & 850 & 943 & 973 & 1035 & 1045 & 1081\end{array}$

11661243

$\begin{array}{llllllll}687 & 763 \quad 830 & 913 & 931 & 1035 & 1081 & 1154\end{array}$

$\begin{array}{llllllll}734 & 792 & 951 & 1040 & 1155 & 1182,1231 & 1332\end{array}$

69776383287596810601122117312351298

$\begin{array}{lllllllll}690 & 822 & 850 & 950 & 1030 & 1060 & 1122 & 1170 & 1230\end{array}$

12771315

Кроме соединений, представленных в табл. 6, весьма вероятным является присутствие во фракции $156-158^{\circ}$ газбензина камерных печей 3-изопропилтиофена.

\section{Л И Т Е Р А У Р А}

1. Р. Д. Оболенцев, Б. В. Ай в азов, Распределение прямой гонки, вырабатываемых из сернистых нефтей, Сб. Химия сераорганических соединений, содержащихся в нефтях и нефтепродуктах, Башкирск. филиал АН СССР, M., 1959. 
2. Р. Д. О боленцев, А. А. Р а то в ск ая, К вопросу о методе группового определения сераорганических соединений, предложенном Башкирским филиалом АН СССР, Сб. Химия сераорганических соединений, содержащихся в нефтях и нефтепродуктах, Башкирск. филиал АН СССР, М., 1959.

3. И. А. У ск, И. Г. С толе р, Изыскание способов улучшения качества сланцевого бензина, Сб. Горючие сланцы. Химия и технология, вып. 2, АН ЭССР, Таллин, 1956.

4. П. Когерман,, К. Лутс, Ю. Х юссе, Химия эстонских сланцев, ОНТи ГХТИ, 1934.

5. Х. А. Силл анд, О групповом составе сернистых соединений сланцевой смолы, Тр. Таллинск. политехн. ин-та, Сер. А, № 97, 1957.

6. Х. А. С илланд, О последовательном определении классов сернистых соединений в сланцевой смоле, Тр. Таллинск. политехн. ин-та, Сер. А, № 97, 1957.

7. I. J. Dodonow, E. Soschestwenskaja, Ber. Dtsch. chem. Ges., 59, 1926, S. 2202 .

8. Г. Л. Ст а дников, А. Е. В ейцм ан, Ж. реф. физ.-хим. обществ, МІХ, 1927, стр. 9

9. Г. Л. Стадников, А. С. Броун, Е. М. Зеленин а, «Горючие сланцы», № 5, 1934, стр. 33 .

10. L. Lun d qu ist, Oil Shale and Cannel Coal, Vol. 2, London. 1951, p. 621.

11. S. W. Kinn ey, J. R. S m it h, J. S. B a 1 l, Anal. Chem., 24, 1952, p. 1749.

12. А. Я. А а рна, К. А. К а ск, Об определении химического группового состава средних фракций сланцевой смолы метедом хроматографического анализа, Тр. Таллинск. политехн. ин-та, № 51, 1953.

13. А. Т. Кылль, О.Г. Эй зен, С. В. Киви яяхк, Т. Н. Л аус, С. Э. Ранг, О групповом составе смолы термической переработки мелкосернистого сланца с применением твердого теплоносителя, Сб. Горючие сланцы. Химия и технология, № 3, Таллин, 1960.

14. L. S. L e vit t, E. Howard, Anal. Chem., 25, 1953, p. 196.

15. Р. Д. О боленцев, Б. В. А й в а зов, Г. В. Г а л е е в а, Аннотированный бюллетень научных работ, Башкирск. филиал АН СССР, Уфа, 1958, стр. 35.

16. C. J. Thomson, H. J. Coleman, H. T. Ra11, H. M. S mith, Anal. Chem., 27,1955 , p. 175.

17. Howard D. Harto u gh, Thiophene and Its Derivatives, 65, Interscience Publishers, New York-London, 1952.

\section{Ннститут химии}

Академии наук Эстонской ССР
Поступила в редакцию

27. II 1960

\title{
POLEVKIVIBENSIINI VÄÄVLIUUHENDITE KEEMILISEST KOOSTISEST
}

\author{
o. Eisen, \\ tehnikakandidaat \\ J. Rikken \\ Resümee
}

Senistes Balti pōlevkivibasseini pōlevkiviōli keemilist koostist käsitlevates arvukates Łöödes on väävliühendite uurimisele suhteliselt vähe tähelepanu osutatud.

Käesolevas töös on uuritud pōlevkivibensiini väävliühendite grupilist koostist ja identifitseeritud esmakordselt rida individuaalseid väävliühendeid.

Tunnelahjude ja tahke soojusekandjaga utteseadme bensiin ning kamberahjude gaasbensiin rektifitseeriti 60 teoreetilise taldriku eraldusteravusega destillatsiooniseadmes kitsasteks fraktsioonideks. Nende uurimisel selgus, et väävliühendid on koondunud peamiselt järgmistesse keemispiirkondadesse: $79-80^{\circ}, 107-110^{\circ}, 132-137^{\circ}, 155-160^{\circ}$ ine.

Vastavates maksimaalse ja minimaalse väävlisisaldusega piirkondades māärati väävliühendite grupiline koostis. Leiti, et $75 \%$ väävliühenditest satub kromatografeerimisel aromaatsete ühendite fraktsiooni.

Rektifitseerimise ja kromatografeerimisega rikastatud väävliühendite kontsentraatidest identifitseeriti infrapunase spektraalanalüüsi abil tiofeen, 2-metüültiofeen, 3-metüültiofeen, 2-etüültiofeen, 2,3-dimetüültiofeen ja 2,5-dimetüültiofeen. 


\title{
ON THE CHEMICAL COMPOSITION OF OIL SHALE GASOLINE SULFUR COMPOUNDS
}

\author{
O. Eisen, J. Rikken
}

\section{Summary}

In the numerous works dealing with the chemical composition of the shale oil of the Baltic oil shale basin comparatively little attention has been paid to the study of sulfur compounds.

The authors of this paper have studied the group composition of the sulfur compounds of oil shale gasoline, indentifying, for the first time, a number of individual sulfur compounds.

Tunnel-oven gasoline, gasoline obtained in carbonization plants with a solid heat carrying agent, as well as chamber-kiln gas gasoline were rectified to narrow fractions in a distilling apparatus with a selectivity of 60 theoretical plates. An examination of these fractions showed that sulfur compounds were concentrated mainly in the following boiling-ranges: $79-86^{\circ}, 107-110^{\circ}, 132-137^{\circ}, 155-160^{\circ} \mathrm{C}$, etc.

The group composition of sulfur compounds was defined in the corresponding ranges containing the maximal and minimal amount of sulfur compounds.

At chromatography $75 \%$ of sulfur compounds were found to belong to the fraction of aromatic compounds.

With the help of infra-red spectral analysis the authors identified in the rectified and chromatographed concentrates of sulfur compounds: thiophene, 2-methylthiophene, 3-methylthiophene, 2-ethylthiophene, 2.3-dimethylthiophene and 2.5-dimethylthiophene. Academy. of Sciences of the Estonian S.S.R.,
Institute of Chemistry
Received

Febr. 27th, 1960 